\title{
EVALUATION OF METHODOLOGIES OF URINE COLLECTION TO ESTIMATE MICROBIAL SYNTHESIS IN BOVINES DIETS CONTAINING LIPIDS OR NOT
}

\author{
AVALIAÇÃO DE METODOLOGIAS DE COLETA DE URINA PARA ESTIMAR A \\ SÍNTESE MICROBIANA EM DIETAS DE BOVINOS CONTENDO OU NÃO \\ LIPÍDEOS
}

\author{
Laila Cecília Ramos BENDIA $^{1}$; Carlos Augusto de Alencar FONTES ${ }^{1 \dagger}$; \\ Elizabeth Fonsêca PROCESSI ${ }^{1}$; Clóvis Carlos SILVEIRA FILHO ${ }^{1}$; \\ Cláudio Teixeira LOMBARDI ${ }^{1}$; Paulo Roberto Silveira PIMENTEL ${ }^{2}$; \\ Ronaldo Lopes OLIVEIRA ${ }^{2}$; Leilson Rocha BEZERRA ${ }^{3}$; Tiago Cunha ROCHA ${ }^{4 *}$ \\ 1. State University of North Fluminense Darcy Ribeiro, Department of Animal Science, Campos dos Goytacazes, Rio de Janeiro, Brazil. \\ †in memoriam. 2. Federal University of Bahia, Department of Animal Science, Salvador, Bahia, Brazil; 3. Federal University of \\ Campina Grande, Center of Health and Agricultural Technology, Patos, Paraíba, Brazil; 4. State University of the Tocantina Region of \\ Maranhão, Imperatriz, Maranhão, Brazil. *tiagoticuro@yahoo.com.br
}

ABSTRACT: This study investigated the effectiveness of the urine sample collection method in predicting the volume urinary and synthesis of microbial nitrogen. Eight fistulated steers were used with accessible rumens and kept in individual stalls. Their diets consisted of corn silage; corn silage + concentrate; corn silage + concentrate with addition of lipids in the form of soybean oil; and corn silage + concentrate with addition of lipids in the form of soybean grains. Estimates of microbial protein synthesis were obtained based on the urinary excretion of purine derivatives. There was no effect of diets on daily creatinine excretion $(\mathrm{P}>0.05)$. There were differences $(\mathrm{P}<0.05)$ between the urinary volume and microbial synthesis values determined by the total urine collection and those estimated from the urine spot samples and equations proposed by different authors. The estimation of microbial synthesis based on the urine excretion of purine derivatives should be performed from the total collection of the urine for a period of 24 hours.

KEYWORDS: Corn silage. Creatinine excretion. Purine derivatives. Soybeans. Soybean oil.

\section{INTRODUCTION}

Crude microbial protein (CPmic) synthesis plays an important role in ruminant nutrition as it provides most of the metabolizable protein requirements, representing $50 \%$ to $80 \%$ of the amino acids that flow into the animal's small intestine (FIRKINS; YU; MORRISON, 2007; NGUYEN et al., 2017). In this sense, maximizing microbial production efficiency would therefore improve animal productivity (HACKMANN; FIRKINS, 2015).

In this sense, it is necessary to determine the amount of CPmic produced, however, traditional methods for quantifying microbial production are laborious, they require fistulated animals and may present inconsistent results due to difficulties in measuring the flow of digestion and obtaining a representative sample of the rumen microorganisms (BRODERICK; MERCHEN, 1992). On the other hand, the search for less invasive techniques in animal experimentation favored the use of urinary purine derivative (PD) excretion in urine to quantify microbial protein synthesis as an alternative to cannulated animal use (KOZLOSKI et al., 2017).

Additionally, the measurement of the urinary volume through creatine has allowed for the quantification of daily PD excretion without total urine collection from a single urine sample (spot) (VALADARES et al., 1999), which allows us to not only obtain data simply and without discomfort of animal but also allows for the application of this technique at the farm level.

In the literature, it is possible to observe studies suggesting the use of a urine spot to estimate the urinary excretion of PD (VALADARES et al., 1999; BARBOSA et al., 2006; CHIZZOTTI et al., 2006). However, in these studies, daily creatinine excretion was obtained using the product of the urinary volume and the total creatinine concentration quantified in the experiment. Thus, the indication of the spot sample to estimate the excretion of DP may not be applicable when only the urine spot sample is collected.

Lipid supplementation has two effects on the synthesis of CPmic, and these effects would be 
antagonistic. A negative effect on microbial metabolism opposes the favorable effect of defaunation on the synthesis of the microbial biomass, while the response of lipid supplementation to CPmic would depend on the net effect of these two factors (VAN NEVEL; DEMEYER, 1981).

Considering the importance of CPmic in the protein nutrition of ruminants, as well as the interest in adding lipids to the diet and the need to obtain simple methods that allow the quantification of the microbial synthesis in a precise way, this study aimed to evaluate the effectiveness of the predicting the volume urinary from urine spot samples, taking the values obtained by total urine collection as a reference and determining a synthesis of microbial protein in confined cattle supplemented or not supplemented with different lipid sources were also assessed.

\section{MATERIAL AND METHODS}

\section{Location and ethical considerations}

This study was approved by the Research Ethics Committee of the State University of North Fluminense, protocol number 168/12. The experiment was carried out at the Animal Husbandry Research Support Unit, the Animal Science and Animal Nutrition Laboratory of the Northern Fluminense State University - Darcy Ribeiro (UENF), Campos dos Goytacazes, RJ.

Animals, experimental treatments and diets

Eight rumen-fistulated crossbred steers with an average initial body weight of $300 \mathrm{~kg}$ were used and kept in individual, partially covered stalls with concrete floors, drinking fountains and a trough.
BENDIA, L. C. R. et al.

The animals were vermifuged and submitted a preexperimental period of 21 days for adaptation to experimental facilities and conditions. During this period, all the animals received the same feed, consisting of corn silage and a concentrated ration containing corn and soybean meal.

After the adaptation period, the animals were randomly assigned to two $4 \times 4$ balanced Latin squares, comprising four animals, four diets and four periods, which were conducted simultaneously.

The diets comprised the following:

CS - Corn silage;

$\mathrm{CS}+\mathrm{C}-70 \%$ corn silage and $30 \%$

concentrate;

CS + OS - 70\% corn silage and 30\% concentrate containing 5\% lipids from soybean oil;

CS + GS $-70 \%$ of corn silage and $30 \%$ of concentrate, containing $5 \%$ of lipids derived from soybean grains.

The experimental periods lasted eighteen days, with the first fourteen days used for the adaptation of the animals and the data collections performed in the last four days.

Feeding was done twice a day in equal portions at 8:00 am and 4:00 p.m. in the form of a complete mix, aiming to keep leftovers at approximately 5 to $10 \%$ to guarantee ad libitum food consumption. The concentrate was manually mixed into the silage at the time of feeding. The intake was obtained by the difference between the supplied food and the leftovers, with the leftovers being weighed daily and $10 \%$ of their sampled weight being used for further analysis. Table 1 shows the proportion of the ingredients and the composition of the experimental diets.

Table 1. Ingredients and chemical composition of the supplements and pasture

\begin{tabular}{lllll}
\hline Composition & Diets & & \\
\cline { 2 - 4 } Corn silage & $\mathrm{CS}$ & $\mathrm{CS}+\mathrm{C}$ & $\mathrm{CS}+\mathrm{OS}$ & $\mathrm{CS}+\mathrm{GS}$ \\
Grain of soybean & 100 & 70.0 & 70.0 & 70.0 \\
Corn & & & 13.1 & 16.4 \\
Oil soybean & & 16.9 & 3.10 & \\
Limestone & & 0.59 & 0.57 & \\
Soybean meal & & 12.5 & 13.2 & \\
Nutrient & DM basis $(\% \mathrm{DM})$ & & \\
Dry matter (g/kg as fed) & 31.6 & 46.9 & 48.8 & 47.4 \\
Organic matter & 84.5 & 85.5 & 85.7 & 85.9 \\
Crude protein & 6.95 & 12.6 & 12.0 & 12.2 \\
Ether extract & 1.60 & 1.77 & 5.00 & 5.00 \\
NDF $^{1}$ & 54.2 & 40.5 & 41.4 & 39.9 \\
\hline
\end{tabular}

${ }^{\mathrm{I}}$ Neutral detergent fiber 


\section{Collections and laboratory analyses}

At the beginning of each collection period, the animals were weighed. On the 16th and 17th day of each experimental period, the total urine for 24 hours was collected. Urine collections performed in the 24-hour period were obtained using collector funnels adapted to the animals. Rubber hoses were coupled to the funnels and the urine was led into plastic containers containing $200 \mathrm{~mL}$ of $20 \%$ sulfuric acid solution $\left(\mathrm{H}_{2} \mathrm{SO}_{4}\right)$. At the end of each 24-hour period, the produced urine was properly measured, homogenized and filtered on filter paper. Then, two urine samples were obtained: one with a volume of $10 \mathrm{~mL}$ diluted with $40 \mathrm{~mL}$ of sulfuric acid $\left(\mathrm{H}_{2} \mathrm{SO}_{4}\right)$ and the other, an undiluted sample of approximately $50 \mathrm{~mL}$. Both of the samples were identified and stored in plastic bottles at $-15^{\circ} \mathrm{C}$ for further creatinine, allantoin and uric acid analysis.

Urine spot samples were obtained four hours after the morning feeding on the days of total urine collection. To do this, the urine from the collection funnels was directed manually to plastic containers and processed in the same way as the samples for the 24-hour total collections.

Estimates of the microbial nitrogen flux were obtained by purine intestinal absorption $(\mathrm{X}$, $\mathrm{mmol} /$ day), estimated based on the excretion of purine derivatives (Y, mmol/day) and metabolic weight (PV 0.75) according to the following equation (VERBIC et al., 1990):

$\mathrm{X}=\frac{\mathrm{Y}-0.385 \mathrm{PV} \mathrm{V}^{\wedge} 0.75}{0.85}$

Where 0.85 is the recovery of the purines absorbed as urine purine derivatives, and 0.385 $\mathrm{PV}^{0.75}$ corresponds to the endogenous contribution to urine excretion.

The intestinal flow of the microbial nitrogenous compounds $(\mathrm{N})(\mathrm{Y}, \mathrm{mmol} /$ day) was estimated as a function of the absorbed microbial purines $(\mathrm{X}, \mathrm{mmol} / \mathrm{day})$ using the following equation (CHEN; GOMES, 1992):

$\mathrm{Y}=\frac{70 \mathrm{X}}{0.83 * 0.116 * 1000}$

Where in 70 represents the $\mathrm{N}$ content in the purines (mg N. $\mathrm{mmol}^{-1}$ ); 0.83 corresponds to the digestibility of the microbial purines; and 0.116 is the N-RNA:N ratio in the bacteria.

The urinary volume (L), estimated from the spot samples, was calculated from the creatinine concentration in the urine spot sample $(\mathrm{mg} / \mathrm{L})$, and the amount of creatinine excreted daily in $\mathrm{mg} / \mathrm{kgBW}$ was:

$\operatorname{Vol}(\mathrm{L})=\frac{\text { BW(Kg) * creatinine excreted }\left(\mathrm{mg}, \mathrm{KgBV} /{ }^{2}\right)}{\text { creatinine concertration }\left(\mathrm{mg}, \mathrm{L}^{-1}\right)}$

For comparison purposes, the daily creatinine (EC) excretions were estimated in three ways:

-From the product of the total volume and creatinine concentration of the total collection;

- By means of the equations proposed in the literature:

-Chizzotti et al. (2004):

$$
\mathrm{CE}(\mathrm{mg} / \mathrm{kgBW})=32,27-0,01093 \mathrm{BW}
$$

-Silva et al. (2012):

\section{$C E(g /$ day $)=0,0345 * B W^{0,9491}$}

Analyses of the creatinine and uric acid were performed using commercial kits (LABTEST; LAGOA SANTA, MINAS GERAIS, BRAZIL), according to the manufacturer's guidelines. The analysis of allantoin in the urine was done using the colorimetric method proposed by Fujihara et al. (1987), as described by Chen and Gomes (1992).

\section{Statistical analysis}

Statistical analyses of daily urinary volume, daily urinary excretion of creatinine and synthesis of microbial nitrogen were performed using the SAS Proc Mixed Procedure for repeated measurements (day aligned in period). The model included the effects of the Latin square, diet, period, day within the period, the diet $x$ Latin square and Latin square $\mathrm{x}$ period interactions.

The AR (1) and composite symmetry (CS) covariance structures were tested, using the AR (1) structure, based on the information criteria: AIC, AICC, BIC and -2 Res Log Likelihood.

\section{RESULTS AND DISCUSSION}

The estimated volume of the urine based on the spot sample starting from the actual excretion of creatinine (Estimated-ExR) differed $(\mathrm{P}<0.05)$ from the volume observed at 24 hours of collection for the four diets (Table 2). This indicated that the creatinine concentrations in the spot samples were not equal to their concentration in the total urine. 
Table 2. Mean and confidence intervals (95\%) for the daily urinary volumes (L) observed (OBS) and estimated (EST) per diet.

\begin{tabular}{|c|c|c|c|c|}
\hline \multirow[t]{2}{*}{ Variables } & \multicolumn{4}{|l|}{ Diets } \\
\hline & $\mathrm{CS}$ & $\mathrm{CS}+\mathrm{C}$ & $\mathrm{CS}+\mathrm{OS}$ & $\mathrm{CS}+\mathrm{GS}$ \\
\hline & \multicolumn{4}{|c|}{ Urinary Volume (L) } \\
\hline OBS & $5,51 \pm 1.51 \mathrm{aB}$ & $4.81 \pm 1.54 \mathrm{aB}$ & $5.40 \pm 1.52 \mathrm{aB}$ & $5.90 \pm 1.52 \mathrm{aB}$ \\
\hline $\mathrm{EST}^{-E_{x}{ }^{1}}$ & $9,67 \pm 3.17 \mathrm{aA}$ & $9.12 \pm 2.72 \mathrm{aA}$ & $8.57 \pm 2.89 \mathrm{aA}$ & $8.86 \pm 2.93 \mathrm{aA}$ \\
\hline EST- $\mathrm{I}^{2}$ & $13.4 \pm 6.01 \mathrm{aA}$ & $11.7 \pm 5.33 \mathrm{aA}$ & $13.2 \pm 5.51 \mathrm{aA}$ & $12.7 \pm 5.52 \mathrm{aA}$ \\
\hline EST- II ${ }^{3}$ & $11.4 \pm 5.52 \mathrm{aA}$ & $10.6 \pm 4.85 \mathrm{aA}$ & $11.9 \pm 5.02 \mathrm{aA}$ & $11.5 \pm 4.99 \mathrm{aA}$ \\
\hline
\end{tabular}

Means followed by lower/upper case letters in the rows/columns differ according to the $95 \%$ confidence interval

${ }^{1}$ Estimated starting from the creatinine concentration in the spot sample and daily creatinine excretion obtained in the experiment by total collection of urine

${ }^{2}$ Equation I proposed by Chizzotti et al. (2004): CE (mg/kgBW) $=32.27-0.01093 \mathrm{BW}$

${ }^{3}$ Equation II proposed by Silva et al. (2012): CE (g/day) $=0.0345 \mathrm{xBW}^{0.9491}$

The spot sample methodology is based on the creatinine concentration in the sample, which should be representative of its concentration in the total urine excreted in 24 hours, and in the estimation of the daily creatinine excretion, based on the animal's body weight using equations developed by different authors. These equations assume that creatinine excretion is constant or may only have slight variation, depending on the protein content of the animal.

Random variations in creatinine concentration in the spot sample and possible variations in the creatinine excretion per $\mathrm{kg}$ body weight would, therefore, be uncontrollable sources of error that would prevent the correct estimation of the volume of urine excreted. These two sources of error may explain the large difference $(\mathrm{P}<0.05)$ observed between the total urine excretion values and the estimated values using the equations of Chizzotti et al (2004) and Silva et al. (2012) (Table 2).

Based on the results partially obtained by the total collection, the use of the spot sample can lead to erroneous results when estimating the daily creatinine excretion using the equations proposed in the literature. The use of equations obtained in different experiments to estimate daily creatinine excretion can be done if it is assumed that the creatinine excretion is constant, a function of body weight, and not affected by diet (FAICHNEY; WELCH; BROWN, 1995). However, because creatinine is derived from the protein metabolism of muscle tissue and excreted proportionally to the amount of muscle tissue in the animal (SCHUTTE et al., 1981), it is possible that there are variations in the daily creatinine excretions expressed as a function of animal weight because the animals present different proportions of tissues at each stage of development.

There were no differences between the urinary volume observed and the estimates in the diets (EST-ExR, EST-I, and EST-II), as reported by several authors (VAGNONI et al. al. 1997). Diet has little effect on creatinine excretion.

The use of urine spot samples also requires that the concentrations of creatinine and purine derivatives (PD) in the spot represent the mean daily value of creatinine and $\mathrm{PD}$ excretion and that there is little variation in their excretion throughout the day (CHEN et al., 1995). In this experiment, spot sample collection was performed 4 hours after morning feeding between 12:00 and 13:00 hours, which may have overestimated the urinary volume since the urine creatinine concentration is low at that time (VALADARES et al., 1999, KOZLOSKI et al., 2005). Urinary volume may have been underestimated, because unlike the nocturnal period, when urine production tends to decrease considerably due to a greater resorption of water and electrolytes (GÜRTLER et al., 1987) and consequently increasing creatinine concentration. In urine, it is likely that at the moment urine output was higher in the collection, diluting creatinine concentrations.

Thus, the differences between the urinary and estimated volumes observed in this study can be attributed to the error introduced using equations obtained in other experiments to estimate the daily creatinine excretion and to possible differences in the creatinine concentration in the urine spot sample. Because of the urinary values obtained by means of estimates in the present research, the microbial synthesis represented by Nmic in Table 3 was overestimated and presented inaccurate values, as indicated by the confidence intervals. 
Table 3. Mean and confidence intervals (95\%) for the microbial nitrogen (g/day) observed (OBS) and estimated (EST) per diet.

\begin{tabular}{|c|c|c|c|c|}
\hline \multirow[t]{2}{*}{ Variables } & \multicolumn{4}{|l|}{ Diets } \\
\hline & CS & $\mathrm{CS}+\mathrm{C}$ & $\mathrm{CS}+\mathrm{OS}$ & $\mathrm{CS}+\mathrm{GS}$ \\
\hline & \multicolumn{4}{|c|}{ Microbial nitrogen (g/day) } \\
\hline OBS & $30.3 \pm 5.50 \mathrm{~b}$ & $55.2 \pm 5.50 \mathrm{a}$ & $57.4 \pm 5.50 \mathrm{a}$ & $52.2 \pm 5.60 \mathrm{a}$ \\
\hline EST-ExR $^{1}$ & $97.2 \pm 97.2 \mathrm{a}$ & $133 \pm 87.1 \mathrm{a}$ & $84.1 \pm 84.1 \mathrm{a}$ & $88.5 \pm 88.5 \mathrm{a}$ \\
\hline EST- $\mathrm{I}^{2}$ & $135 \pm 118 \mathrm{a}$ & $157 \pm 102 \mathrm{a}$ & $122 \pm 108 \mathrm{a}$ & $141 \pm 108 \mathrm{a}$ \\
\hline EST- II ${ }^{3}$ & $127 \pm 112 \mathrm{a}$ & $142 \pm 95.5 \mathrm{a}$ & $111 \pm 99.4 \mathrm{a}$ & $127 \pm 99.9 \mathrm{a}$ \\
\hline
\end{tabular}

Means followed by lower/upper case letters in the rows/columns differ according to the $95 \%$ confidence interval

${ }^{1}$ Estimated starting from the creatinine concentration in the spot sample and daily creatinine excretion obtained in the experiment by total urine collection

${ }^{2}$ Equation I proposed by Chizzotti et al. (2004): CE (mg/kgBW) $=32.27-0.01093 \mathrm{BW}$

${ }^{3}$ Equation II proposed by Silva et al. (2012): CE (g/day) $=0.0345 \mathrm{xBW}^{0.9491}$

Variations in the PD concentrations in the spot sample throughout the day were also reported by Chen et al. (1992a). The low correlation between the daily excretion of PD and the concentration of PD in the spot samples collected at 6-hour intervals were also observed by Nsahlai, Osuji and Umunna (2000).

The amount of microbial purine bases that reach the small intestine may not be constant throughout the day because it depends on the balance between the synthesis and degradation of microbial proteins in the rumen. Additionally, for a given food, the amount of microbial protein is dependent on the intake, digestion rate, and passage.

Chen et al. (1992b) suggested the use of creatinine to adjust the variation in the concentration of $\mathrm{PD}$ in the urine by means of the index [PD, mmol]: [creatinine, mmol] $* \mathrm{PV}^{0.75}$. However, the disadvantage of this equation lies in the high variability observed for creatinine excretion between animals and between days, which would inevitably be added to this ratio. In addition, the use of spot samples may not have sufficient sensitivity to compare treatments if there is little difference in the passage of microbial protein to the small intestine between the treatments (CHEN et al., 1995).

Creatinine excretion was not affected by diet $(\mathrm{P}>0.05)$ (Table 4). Although this was not shown in the table, the day of the collection also had no effect $(\mathrm{P}>0.05)$ on creatinine excretion.

Table 4. Mean, standard error (SD) and probability levels for creatinine excretions in $\mathrm{mg} / \mathrm{BW}$ and $\mathrm{mg} / \mathrm{BW}^{0.75}$ for bovines supplemented or not supplemented with different lipid sources.

\begin{tabular}{|c|c|c|c|c|c|c|c|c|}
\hline \multirow[t]{2}{*}{ Variables } & \multicolumn{4}{|c|}{ Diets } & \multirow{2}{*}{ MSE } & \multicolumn{3}{|c|}{ Contrasts } \\
\hline & CS & $\mathrm{CS}+\mathrm{C}$ & $\mathrm{CS}+\mathrm{OS}$ & $\mathrm{CS}+\mathrm{GS}$ & & C1 & $\mathrm{C} 2$ & C3 \\
\hline $\mathrm{mg} / \mathrm{kgBW}$ & 21.6 & 20.7 & 21.5 & 20.2 & 1.01 & 0.43 & 0.86 & 0.29 \\
\hline $\mathrm{mg} / \mathrm{BW}^{0,75}$ & 96.9 & 88.1 & 92.7 & 85.6 & 4.94 & 0.10 & 0.83 & 0.19 \\
\hline
\end{tabular}

$\mathrm{C} 1=\mathrm{CS}$ vs other diets; $\mathrm{C} 2=\mathrm{CS}+\mathrm{C}$ vs $\mathrm{CS}+\mathrm{OS}$ e $\mathrm{CS}+\mathrm{GS}, \mathrm{C} 3=\mathrm{CM}+\mathrm{OS}$ vs $\mathrm{CS}+\mathrm{GS}$.

The absence of the effect of the collection day on daily creatinine excretion agrees with the observations described by Valadares et al. (1997) and Barbosa et al. (2006), who did not find differences in the creatinine excretion obtained during 12, 24, 48 or 72 hours of collection for six consecutive days. This concluded that the representative samples of the urine can be obtained in a collection period of 24 hours.

\section{CONCLUSION}

The spot sample does not allow the estimation of microbial protein synthesis, based on the urinary excretion of purine derivatives, requiring a total collection of the urine, which can be performed for a period of 24 hours.

RESUMO: Este estudo investigou a eficácia do método de coleta de amostras de urina sobre a predição do volume urinário e síntese de nitrogênio microbiano. Oito novilhos fistulados foram utilizados com rúmen acessível e mantidos em baias individuais. Suas dietas consistiram de silagem de milho; silagem de milho + concentrado; silagem de milho + concentrado com adição de lipídios na forma de óleo de soja; e 
Evaluation of methodologies...

BENDIA, L. C. R. et al.

silagem de milho + concentrado com adição de lipídios na forma de grãos de soja. Estimativas de síntese de proteína microbiana foram obtidas com base na excreção urinária de derivados de purina. Não houve efeito de dietas na excreção diária de creatinina $(\mathrm{P}>0,05)$. Houve diferenças $(\mathrm{P}<0,05)$ entre o volume urinário e os valores de síntese microbiana determinados pela coleta total de urina e os estimados a partir das amostras de manchas de urina e equações propostas por diferentes autores. A estimativa da síntese microbiana baseada na excreção de urina dos derivados de purina deve ser realizada a partir da coleta total da urina por um período de 24 horas. Soja.

PALAVRAS-CHAVE: Derivados de purina. Excreção de creatinina. Óleo de soja. Silagem de milho.

\section{REFERENCES}

BARBOSA, A. M.; VALADARES, R. F. D.; VALADERES FILHO, S. C.; VÉRAS, R. M. L.; LEÃO, M. I.; DETMANN, E.; PAULINO, M. F.; MARCONDES, M. I.; SOUZA, M. A. Effect of urinary collection days, concentrate levels and protein sources on creatinine, urea and purine derivatives excretions and microbial protein synthesis in Nellore cattle. Revista Brasileira de Zootecnia. v.35, n.3, p.870-877, 2006. http://dx.doi.org/doi: 10.1590/S1516-35982006000300033

BRODERICK, G. A.; MERCHEN, N. R. Markers for quantifying microbial protein synthesis in the rumen. Journal Dairy Science. v. 75, p. 2618-2632, 1992. http://dx.doi.org/doi:10.3168/jds.S0022-0302(92)78024-2

CHEN, X. B.; GOMES, M. J. Estimation of microbial protein supply to sheep and cattle based on urinary excretion of purine derivatives - an overview of technical details. Bucksburnd: Rowett Research Institute, International Feed Resources Unit, 1992, 21p.

CHEN, X. B.; GRUBIC, G.; ORSKOV, E. R.; OSUJI, P. Effect of feeding frequency on diurnal variation in plasma and urinary purine derivatives in steers. Animal Production, v. 55, p.185-191, 1992a. http://dx.doi.org/doi:10.1017/S0003356100037442

CHEN, X. B.; CHEN, Y. K.; FRANKLIN, M. F.; ORSKOV, E. R.; SHAND, W. J. The Effect of feed intake and body weight on purine derivative excretion and microbial protein supply in sheep. Journal Animal Science. v. 70, p. 1534-1542, 1992 b. http://dx.doi.org/doi: 10.2527/1992.7051534x

CHEN, X. B.; MEJIA, A. T.; KYLE, D. J.; ORSKOV, E. R. Evaluation of the use of the purine derivative: creatinine ratio in spot urine and plasma samples as an index of microbial protein supply in ruminants: studies in sheep. Journal of Agricultural Science. v. 125, p. 137-143, 1995.

http://dx.doi.org/doi:10.1017/S002185960007458X

CHIZZOTTI, M. L.; VALADARES FILHO, S. C.; VALADARES, R. F. D. Excreção de creatinina em novilhos e novilhas. In: REUNIÃO ANUAL DA SOCIEDADE BRASILEIRA DE ZOOTECNIA, 41., 2004, Campo Grande. Anais...Campo Grande: 2004. (CD-ROM).

CHIZZOTTI, M. L.; VAADARES FILHO, S. C.; VALADRES, R. F. D.; CHIZZOTTI, F. H. M.; CAMPOS, J. M. S.; MARCONDES, M. I; FONSECA, M. A. Intake, digestibility and urinary excretion of urea and purine derivatives in heifers with different body weights. Revista Brasileira de Zootecnia, v. 35, n.4, p.1813-1821, (supl.), 2006. http://dx.doi.org/doi:10.1590/s1516-35982006000600032

FAICHNEY, G. J.; WELCH, R. J.; BROWN, G. H. Prediction of the excretion of allantoin and total purine derivatives by sheep from the 'creatinine coefficient'. Journal of Agricultural Science, v. 125, p. 425-428, 1995. http://dx.doi.org/doi:10.1017/S0021859600084938 
FIRKINS, J. L.; YU, Z.; MORRISON, M. Ruminal nitrogen metabolism: perspectives for integration of microbiology and nutrition for dairy. Journal of Dairy Science, v. 90, p. E1-E16, 2007.

http://dx.doi.org/doi:10.3168/jds.2006-518

FUJIHARA, T; ORSKOV, E. R.; REEDS, P. J.; KYLE, D. J. The effect of protein infusion on urinary excretion of purine derivatives in ruminants nourished by intragastric nutrition. Journal of Agricultural Science, v. 109, p 7-12, 1987. http://dx.doi.org/doi:10.1017/S0021859600080916

GÜRTLER, H. et al. Fisiologia veterinária. 4.ed. Rio de Janeiro: Guanabara Koogan, 1987. 612p

HACKMANN, T. J.; FIRKINS, J. L. Maximizing efficiency of rumen microbial protein production. Frontiers in microbiology, v. 6, p. 465, 2015. http://dx.doi.org/doi:10.3389/fmicb.2015.00465

KOZLOSKI, G. V.; FIORENTINI, G.; HARTER, C. J.; SANCHES, L. M. B. Creatinine use as an indicator of urinary excretion in ovines. Ciência Rural, v. 35, n. 1, p. 98-102, 2005. http://dx.doi.org/doi:10.1590/S010384782005000100015

KOZLOSKI, G. V.; STEFANELLO, C. M.; OLIVEIRA, L.; FILHO, H. R.; KLOPFENSTEIN, T. J. Evaluation of urinary purine derivatives in comparison with duodenal purines for estimating rumen microbial protein supply in sheep. Journal of animal science, v. 95, n. 2, p. 884-891, 2017.

http://dx.doi.org/doi:10.2527/jas.2016.0840

NGUYEN, T. T. G.; WANAPAT, M.; PHESATCHA, K.; KANG, S. Effect of inclusion of different levels of Leucaena silage on rumen microbial population and microbial protein synthesis in dairy steers fed on rice straw. Asian-Australasian journal of animal sciences, v. 30, n. 2, p. 181, 2017.

https://doi.org/10.5713/ajas.15.0948

NSAHLAI, I. V.; OSUJI, P. O.; UMUNNA, N. N. Effect of form and of quality of feed on the concentrations of purine derivatives in urinary spot samples, daily microbial $\mathrm{N}$ supply and predictability of intake. Animal Feed Science and Technology. v. 85, p. 223-238, 2000. http://dx.doi.org/doi:10.1016/S0377-8401(00)00138-3

SCHUTTE, J. E.; LONGHURST, J. C.; GAFFNEY, F. A.; BASTIAN, B. C.; BLOMQVIST, C. G. Total plasma creatinine: an accurate measure of total striated muscle mass. Journal of Applied Physiology, v.51, p.762-766, 1981. http://dx.doi.org/doi:10.1152/jappl.1981.51.3.762

SILVA, L. F. C.; VALADARES FILHO, S. C.; CHIZZOTTI, M. L.; ROTTA, P. P.; PRADO, L. F.; VALADARES, R. F. D.; ZANETTI, D.; BRAGA, J. M. S. Creatinine excretion and relationship with body weight of Nellore cattle. Brazilian Journal of Animal Science, v. 41, p. 807-810, 2012.

http://dx.doi.org/doi:10.1590/S1516-35982012000300046

VAGNONI, D. B.; BRODERICK, G. A.; CLAYTON, M. K.; HATFIELD, R. D. Excretion of purine derivatives by Holstein cows abomasally infused with incremental amounts of purines. Journal Dairy Science, v. 80, p. 1695-1702, 1997. http://dx.doi.org/doi:10.3168/jds.S0022-0302(97)76101-0

VALADARES, R. F. D.; GONÇALVES, L. C.; SAMPAIO, I. B.; RODRIGUES, N. M.; SILVA, J. F. C. Níveis de proteína em dietas de bovinos. 2. Consumo, digestibilidades e balanço de compostos nitrogenados. Brazilian Journal of Animal Science, v. 26, p.1259-1263, 1997.

VALADARES, R. F. D.; BRODERICK, G. A.; VALADARES FILHO, S. C.; CAYTON, M. K. Effect of replacing alfalfa with high moisture corn on ruminal protein synthesis estimated from excretion of total purine derivatives. Journal of Dairy Science, v.8, p.2686- 2696, 1999. http://dx.doi.org/doi:10.3168/jds.S00220302(99)75525-6 
VAN NEVEL, C. J.; DEMEYER, D. I. Effect of methane inhibitors on the metabolism of rumen microbes in vitro. Archives of Animal Nutrition, v. 31, n.2, p. 141-151, 1981.

http://dx.doi.org/doi:10.1080/17450398109434330

VERBIC, J.; CHEN, X. B.; MACLEOD, N. A.; ORSKOV, E. R. Excretion of purine derivatives by ruminants:Effect of microbial nucleic acid infusion on purine derivative excretion by steers. Journal of Agricultural Science. v. 114, p. 243-248, 1990. http://dx.doi.org/doi:10.1017/S0021859600072610. 